\title{
PENERAPAN METODE SIMPLE HILL CLIMBING DALAM MENENTUKAN RUTE TERPENDEK PADA PENGIRIMAN (Studi Kasus di Supplier Hotel)
}

\author{
Aji Satriyo \\ e-mail : ajisatriyo.011@gmail.com \\ Teknik Industri, Fakultas Teknik
}

\begin{abstract}
ABSTRAK
Salahsatu permasalahan yang terjadi pada pengiriman adalah banyaknya lokasi (rute) yang dilalui pengemudi sebanyak satu kali kemudian kembali lagi ke titik semula, permasalahan ini disebut Travelling Salesman Problem. Dari permasalahan tersebut dapat diselesaikan menggunakan (SHC) Simple Hill Climbing dimana metode ini bekerja dengan cara menukar titik untuk mencari lintasan rute yang lebih pendek. Perbandingan antara kondisi awal dengan perhitungan menggunakan (SHC) Simple Hill Climbing menunjukkan perbedaan, pada kondisi awal Rute yang dilalui adalah L1-L2-L3-L4-L5-L6-L1 dengan jarak lintasan bernilai 47,1 Km sedangkan setelah dihitung menggunakan (SHC) Simple Hill Climbing dengan lintasan L1-L3-L2-L4-L5-L6-L1 berrnilai 45,9Km.
\end{abstract}

Kata kunci: rute pengiriman, travelling salesman problem, simple hill climbing

\section{PENDAHULUAN}

Supplier Hotel merupakan bidang usaha yang semakin berkembang, dikarenakan permintaan dari customer yang semakin beragam sesuai dengan karakteristik yang diminta. Untuk itu dalam memberikan pelayanan terbaik bagi customer, perusahaan perlu melakukan perbaikan yaitu pengiriman yang lebih lebih efisien dan tepat waktu. Adapun cara penentuan tempat atau fasilitas pemindahan barang pernah dibahas oleh anshori, et. al., 2017.

Pengiriman merupakan kegiatan pendistribusian barang dari satu lokasi ke lokasi yang lain. Permasalahan dalam pengiriman adalah terdapat beberapa lokasi yang akan dikunjungi, dimana lokasi tersebut dikunjungi sebanyak satu kali kemudian driver atau sopir kembali ke lokasi awal hal tersebut adalah Travelling Salesman Problem (Aristi, 2014). Dalam pengiriman, rute merupakan lintasan yang dilalui oleh Driver atau sopir untuk menuju ke suatu lokasi, dimana lokasi yang dituju yaitu hotel. Rute yang dilalui dalam perjalanan mempunyai jarak tempuh yang diukur dari titik pertama keberangkatan kemudian lokasi pengiriman sampai kembali ke titik semula. Dengan penentuan rute yang tepat, diharapkan dapat mempercepat pengiriman serta memaksimalkan pengiriman tersebut.

Penelitian ini bedasarkan penelitian yang dilakukan (Dermawan, 2018) yang melakukan penelitian dengan judul analisis distribusi obat dengan pendekatan Travelling Salesman Problem pada PT. Pharos cabang Pekanbaru yang memuat permasahan distribusi belum berjalan secara optimal, penentuan optimalisasi rute pendistribusian bertujuan untuk meminimalkan waktu dan biaya transportasi. (Setiyani, 2015) Melakukan penelitian dengan judul Implementasi alogaritma best-first serch (BeFS) pada penyelesaian Travelling Salesman Problem (TSP) studi kasus perjananan di kota yogyakarta, pencarian rute terbaik dan tercepat di kota yogyakarta. Penelitian dari (Dangkua, 2015) yang berjudul penerapan metode hill climbing pada sistem informasi geografis untuk mencari lintasan terpendek serta penghematan biaya menggunakan 2 kombinasi yaitu metode Hill Climbing dan sistem informasi geografis.

\section{METODE PENELITIAN}

Penyelesaian masalah Travelling Salesman Problem adalah mencari mencari lintasan paling pendek. Dalam penelitian ini terdapat 6 lokasi dimana lokasi ke1 sebagai titik awal keberangkatan dan lokasi - lokasi selanjutnya yaitu tujuan pengiriman. Simple Hill Climbing merupakan metode yang pengujiannya yang menerapkan fungsi heuristic, dengan tahapan penyelesaian seperti berikut ini:

Alogaritma Simple Hill Climbing menurut (Nana et al., 2015) :

1. Dimulai dari kedudukan awal, jalankan pengujian : jika tujuan, adalah berhenti dan jika bukan, teruskan dengan kedudukan saat ini sebagai kedudukan awal.

2. Lakukan tahap - tahap berikut hingga menemukan solusi yang dicari, atau hingga tidak menemukan titik baru untuk diaplikasikan pada kedudukan saat ini.

1) Mencari titik yang belum dipakai sebagai permulaan, seterusnya gunakan titik lain untuk ditukar dengan kedudukan baru

2) Mengevaluasi kondisi tersebut

a. Jika titik tersebut adalah tujuan, maka hentikan proses pencarian 
b. Jika tidak titik tujuan, tapi nilainya lebih maksimal atau minimal dari kondisi saat ini, maka buatlah kondisi tersebut sebagai kondisi saat ini

c. Jika kondisi baru kurang baik dari kondisi saat ini, maka teruskan pencarian seperti pada keterangan 2 hingga mendapatkan posisi tujuan dengan bobot terkecil

Sementara itu ada beberapa peluang persoalan terkait metode simple hill climbing :

1. Alogaritma akan terhenti jika mencapai nilai maksimal lokal, yakni penyebutan lintasan saat ini merupakan lintasan terpendek yang akan dilalui, namun belum menentu lintasan tersebut dijadikan sebagai tujuan karena peluang lintasan lain belum teralokasi.

2. Mengurutkan penggunaan posisi yang digunakan untuk melakukan penukaran sehingga dapat berpengaruh untuk menentukan posisi selanjutnya.

Metode ini tidak menjalankan pengujian pada level yang sama, oleh karena itu pada setiap tahap dilakukan pengambilan keputusan yang paling baik diantara lainnya. Dalam menjalankan metoode ini dilakukan dari posisi pertama (kiri) berlanjut dengan melakukan penukaran titik hingga menemukan solusi yang dicari.

\section{HASIL DAN PEMBAHASAN}

Peta tujuan pengiriman dari dari supplier ke 6 hotel tujuan di kota Surabaya.

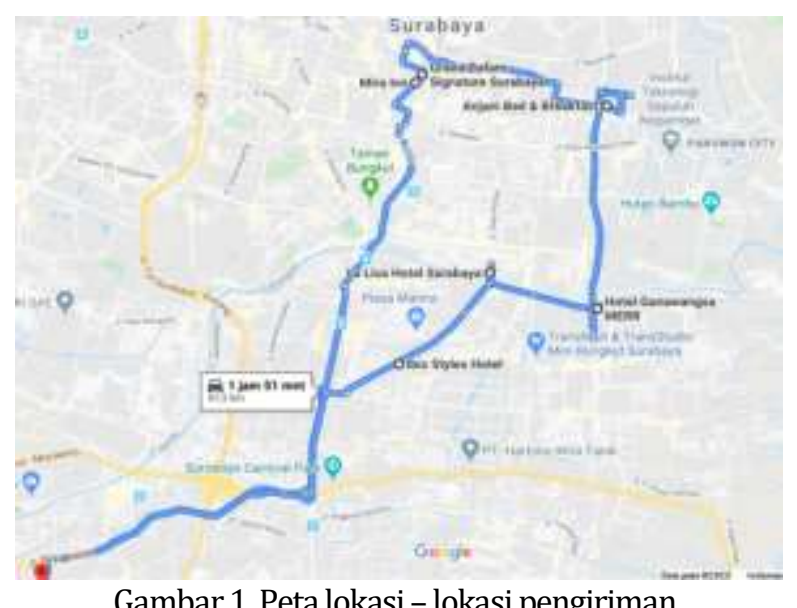

\section{Perhitungan Jarak Berdasarkan Lintasan}

Jarak lintasan dari ke-6 lokasi yang ditempuh oleh Driver Perusahaan Supplier Hotel X tersebut dapat diketahui dari Google Maps (aplikasi peta online), yang selanjutnya dijumlahkan untuk mengetahui jarak lintasan yang akan dilalui oleh driver perusahaan Supplier Hotel X. Adapun perhitungannya dapat dilihat dalam tabel sebagai berikut:
Tabel 1. Jarak Lintasan Awal

\begin{tabular}{|c|c|c|}
\hline No & Lintasan Diperoleh & Jarak \\
\hline 1 & L1 ke L2 & 16,4 \\
\hline 2 & L2 ke L3 & 1,2 \\
\hline 3 & L3 ke L4 & 7,5 \\
\hline 4 & L4 ke L5 & 6 \\
\hline 5 & L5 ke L6 & 3 \\
\hline 6 & L6 ke L1 & 13 \\
\hline
\end{tabular}

Perusahaan memilih rute yaitu diawali dari dari Supplier Hotel X - Hotel Grand Dafam - Hotel De Mira Hotel Anjani B\&B - Hotel Gunawangsa Merr - Hotel La Lisa Sampai kembali ke titik awal yaitu Supplier Hotel X. Lokasi pertama yang dituju oleh Driver yaitu Hotel Grand Dafam yang pada peta (gambar 4.1) letaknya disebelah utara Hotel De Mira, setelahnya yaitu Hotel De Mira yang letaknya disebelah selatan (lokasi pertama), Hotel Grand Dafam menjadi tujuan pertama dikarenakan volume barang yang dikirim lebih banyak serta keterbatasan waktu operasional penerimaan barang, sehingga lokasi tersebut menjadi prioritas utama dalam pengiriman, sedangkan pada lokasi kedua yaitu Hotel De Mira waktu penerimaan barang lebih flexible, hal tersebut juga berlaku untuk lokasi - lokasi pengiriman setelahnya.

Travelling Salesman Problem adalah Permasalahan yang dihadapi Driver atau sopir yang melakukan kunjungan ke lokasi - lokasi yang telah ditentukan sebanyak satu kali kemudian kembali ke titik semula. Dengan menggunakan aplikasi peta online maka dapat diketahui jarak antar lokasi tujuan. Rute yang ditepuh oleh Driver Perusahaan Supplier Hotel yaitu 6 lokasi yang dapat dijelaskan pada peta berikut:

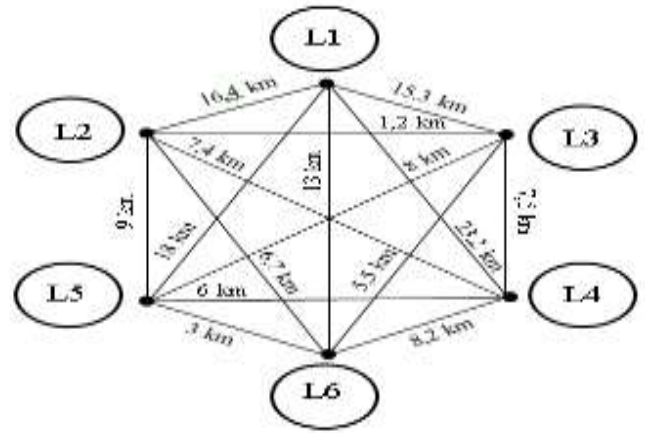

Gambar 2. Kasus Traveling Salesman Problem 6 Lokasi Pada gambar 2 ditunjukkan 6 lokasi yang menjadi pengiriman, adapun dapat dijelaskan sebagai berikut :

L1 = Titik pertama pemberangkatan

L2 = Hotel ke-1

L3 = Hotel ke-3

L4 = Hotel ke- 4

L5 = Hotel ke-5 
Berdasarkan gambar 2, selanjutnya untuk mengetahui jarak satu lintasan maka dijumlahkan. Adapun nilai jaraknya sebagai berikut :

Tabel 2. Jarak Antar 6 Lokasi

\begin{tabular}{|l|r|r|r|r|r|r|}
\hline Lokasi & L1 & \multicolumn{1}{l|}{ L2 } & L3 & L4 & \multicolumn{1}{l|}{ L5 } & \multicolumn{1}{l|}{ L6 } \\
\hline L1 & & 16,4 & 15,3 & 23,2 & 18 & 13 \\
\hline L2 & 16,4 & & 1,2 & 7,4 & 9 & 6,7 \\
\hline L3 & 15,3 & 1,2 & & 7,5 & 8 & 5,5 \\
\hline LA & 23,2 & 7,4 & 7,5 & & 6 & 8,2 \\
\hline L5 & 18 & 9 & 8 & 6 & & 3 \\
\hline L6 & 13 & 6,7 & 5,5 & 8,2 & 3 & \\
\hline
\end{tabular}

Pemecahan permasalahan Travelling Salesman Problem dapat dilakukan menggunakan metode Simple Hill Climbing dilakukan dengan teknik menurak 2 titik yang bersebelahan. Dari fungsi Heuritic yang diterapkan dalam permasalahan Travelling Salesman Problem ini merupakan jarak lintasan yang akan ditempuh. Dalam menemukan nilai jarak lintasan terpendek pada kunjungan ke lokasi - lokasi tujuan sebanyak satu kali, maka dilakukan dengan penukaran, adapun perumusan masalah yaitu :

$$
C(n, r)=C_{r}^{n}=\frac{n !}{r !(n-r) !}
$$

Dengan $n$ merupakan jumlah lokasi dan $r$ merupakan jumlah lokasi yang ditukar, maka didapatkan :

$\mathrm{C}(n, r)=\mathrm{C}_{r}^{n}=\frac{n !}{r !(n-r) !}=\frac{6 !}{2 !(6-2) !}=15$

Bedasarkan hasil diatas, maka diperoleh penukaran sebanyak 15 kombinasi. Dari ke-15 kombinasi akan dipilih lintasan yang paling pendek, Keberangkatan diawali dari lokasi ke-1 dalam pengiriman. Permasalahan Travelling Salesman Problem dimana kondisi awal perjalanan yaitu L1 - L2 - L3 - L4 L4 - L5 - L6 - L1 dengan jarak lintasan yaitu $=47,1 \mathrm{Km}$

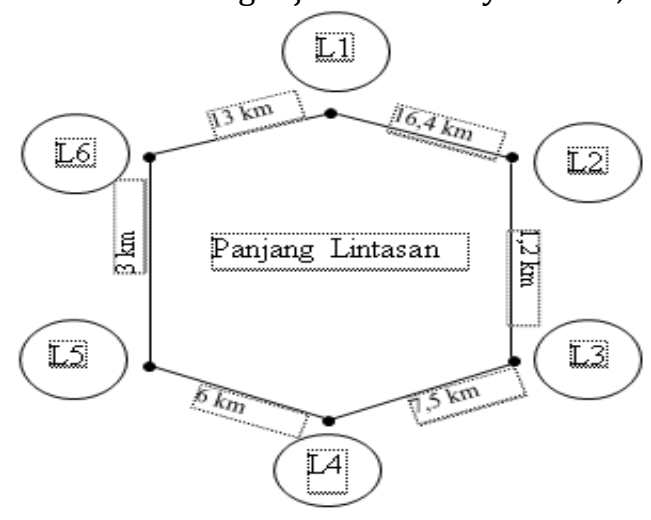

Gambar 3. Jarak antar lokasi

Selanjutnya untuk mengetahui jarak satu lintasan tersebut, maka dijumlahkan sebagai berikut:

Tabel 3. Perhitungan Jarak Lintasan Awal

\begin{tabular}{|c|c|c|}
\hline No & Lintasan Diperoleh & Jarak \\
\hline 1 & L1 - L2 & 16,4 \\
\hline 2 & L2 - L3 & 1,2 \\
\hline 3 & L3 - L4 & 7,5 \\
\hline 4 & L4 - L5 & 6 \\
\hline 5 & L5 - L6 & 3 \\
\hline 6 & L6 - L1 & 13 \\
\hline & Total Jarak & 47,1 \\
\hline
\end{tabular}

\section{Perhitungan Jarak Lintasan Menggunakan Penukaran Titik}

Setelah diketahui jarak pada lintasan awal, maka selanjutnya dilakukan perhitunganuntuk mencari jarak terpendek dari satu lintasan menggunakan teknik penukaran titik dalam metode Simple Hill Climbing. Adapun perhitungannya sebagai berikut:

Tabel 4. Perhitungan Jarak Dengan Penukaran Titik

\begin{tabular}{|c|c|c|c|}
\hline Level & Titik Tukar & Lintasan Diperoleh & Jarak \\
\hline \multirow{5}{*}{$\begin{array}{c}\text { Level } \\
1\end{array}$} & 1. L1, L2 & L2,L1,L3,L4,L5,L6,L2 & 54,9 \\
\hline & .... & & ................. \\
\hline & 6. L2, L3 & L1,L3,L2,L4,L5,L6,L1 & 45,9 \\
\hline & & & ... \\
\hline & 15. L5, L6 & L1,L2,L3,L4,L6,L5,L1 & 54,3 \\
\hline \multirow{5}{*}{$\begin{array}{c}\text { Level } \\
2\end{array}$} & 1. L1, L2 & L2,L1,L4,L3,L5,L6,L2 & 64,8 \\
\hline & …………...................... & 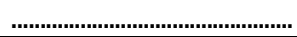 & ................ \\
\hline & 6. L2, L3 & L1,L3,L2,L5,L4,L6,L1 & 52,7 \\
\hline & & .... & ..... \\
\hline & 15. L5, L6 & L1,L3,L2,L6,L5,L4,L1 & 55,4 \\
\hline \multirow{5}{*}{$\begin{array}{c}\text { Level } \\
3\end{array}$} & 1. L5, L6 & L2,L1,L4,L3,L6,L5,L2 & ............... \\
\hline & ...... & & ................ \\
\hline & 6. L2, L3 & L3,L2,L1,L5,L4,L6,L3 & 55,3 \\
\hline & $\ldots \ldots \ldots \ldots$ & ......... & …............. \\
\hline & 15. L5, L6 & L6,L5,L2,L1,L3,L4,L6 & 59,4 \\
\hline
\end{tabular}

Bedasarkan perhitungan pada tabel 1 diketahui bahwa jarak lintasan awal yaitu 47,1 Km, dan setelah dilakukan perhitungan dengan Metode Simple Hill Climbing yang dilakukan dengan cara menukar dua titik yang bersebelahan, hasilnya seperti terlihat pada tabel 2 yang menunjukkan pecarian lintasan terpendek terdapat pada penukaran ke-6 pada level ke-1 yang mempunyai jarak lintasan yaitu 45,9. Perbandingan dengan perhitungan jarak pada kondisi awal, adapun dapat dijelaskan sebagai berikut :

Tabel 5. Perbandingan Jarak Lintasan

\begin{tabular}{|c|c|c|c|}
\hline No & Rute atau Lintasan & Jarak & Selisih \\
\hline 1 & $\begin{array}{l}\text { Perhitungan Jarak } \\
\text { Lintasan pada kondisi } \\
\text { awal }\end{array}$ & 47,1 & \multirow[t]{2}{*}{1,2} \\
\hline 2 & $\begin{array}{l}\text { Perhitungan jarak } \\
\text { lintasan menggunakan } \\
\text { metode }\end{array}$ & 45,9 & \\
\hline
\end{tabular}


Perhitungan Jarak Menggunakan Koordinat Lokasi Setelah melakukan penukaran titik dari ke-6 lokasi dan didapatkan nilai lintasan yang paling pendek, selanjutnya dilakukan perhitungan jarak dengan Koordinat lokasi - lokasi yang dapat diketahui dari peta, adapun gambarnya sebagai berikut:

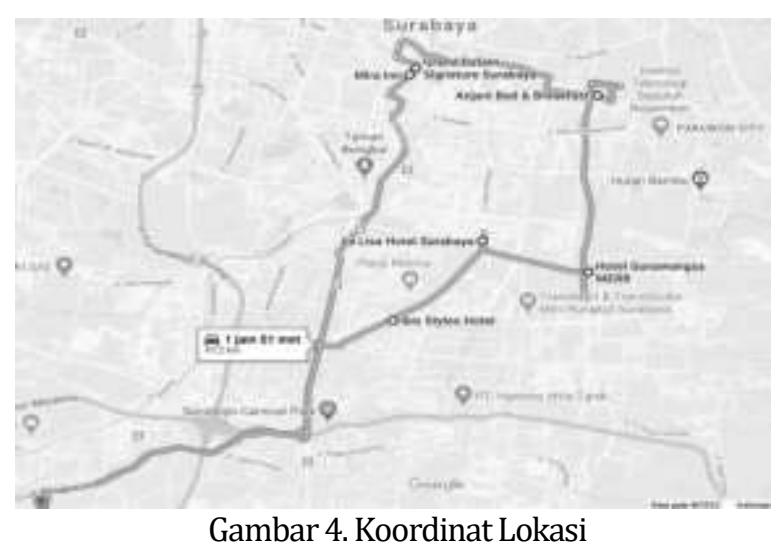

Nilai koordinat dari lokasi - lokasi tersebut, Adapun nilainya sebagai berikut:

Tabel 6. Nilai Titik Koordinat Lokasi

\begin{tabular}{|c|c|c|}
\hline Lokasi ke & $\boldsymbol{X}$ & $\boldsymbol{Y}$ \\
\hline 1 & 3 & 4 \\
\hline 2 & 12 & 16 \\
\hline 3 & 11 & 16 \\
\hline 4 & 17 & 15 \\
\hline 5 & 17 & 9 \\
\hline 6 & 14 & 10 \\
\hline
\end{tabular}

Setelah menghitung dengan rumus Euclidean bedasarkan data dari tabel 6. maka diperoleh nilai jarak antar Koordinat lokasi sebagai berikut:

Tabel 7. Nilai Titik Koordinat Lokasi

\begin{tabular}{|l|r|r|r|r|r|r|r|} 
Lokasi & L1 & L2 & L3 & L4 & L5 & L6 \\
\hline L1 & & 15 & 14,4 & 18,1 & 14,7 & 12,5 \\
\hline L2 & 15 & & 1 & 5 & 9 & 6,3 \\
\hline L3 & 14,4 & 1 & & 6 & 9,6 & 6,7 \\
\hline L4 & 18,1 & 5 & 6 & & 7 & 6,2 \\
\hline L5 & 14,7 & 9 & 9,6 & 7 & & 3 \\
\hline L6 & 12,5 & 6,3 & 6,7 & 6,2 & 3 & \\
\hline
\end{tabular}

Berdasarkan data yang diperoleh pada tabel 7., maka dapat diketahui jarak lintasan pada kondisi awal (lintasan awal) yang biasa ditempuh oleh Driver perusahaan Supplier Hotel X, yang melintasi satu lintasan yaitu L1-L2-L3-L4-L5-L6-L1, selanjutnya digambarkan sebagai berikut:

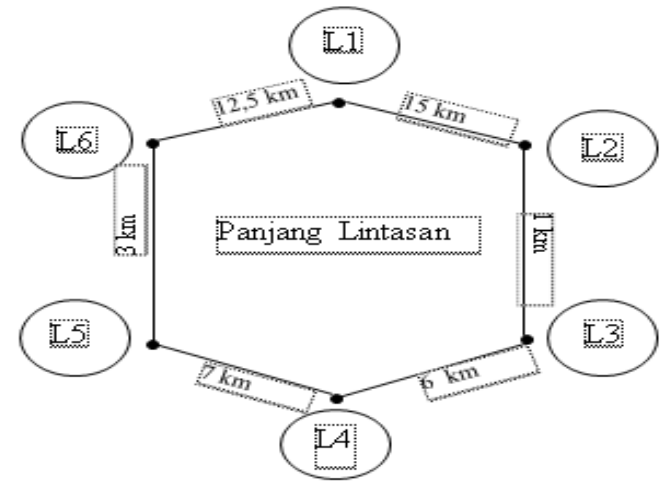

Gambar 5. Jarak lintasan 6 lokasi menggunakan koordinat

Jarak satu lintasan tersebut dapat dihitung dan dijumlahkan seperti ditunjukkan dalam tabel 8 berikut:

Tabel 8. Perhitungan jarak lintasan awal

\begin{tabular}{|c|c|c|}
\hline No & Lintasan Diperoleh & Jarak \\
\hline 1 & L1 - L2 & 15 \\
\hline 2 & L2 - L3 & 1 \\
\hline 3 & L3 - LA & 6 \\
\hline 4 & LA - L5 & 7 \\
\hline 5 & L5 - L6 & 3 \\
\hline 6 & L6 - L1 & 12,5 \\
\hline
\end{tabular}

Sedangkan jika dihitung dengan menggunakan Metode Simple Hill Climbing dengan melakukan teknik penukaran titik. maka dapat dijelaskan pada tabel berikut:

Tabel 9. Perhitungan jarak lintasan dengan metode $S H C$

\begin{tabular}{|c|c|c|}
\hline No & Lintasan Diperoleh & Jarak \\
\hline 1 & L5 - L1 & 14,7 \\
\hline 2 & L1 - L3 & 14,4 \\
\hline 3 & L3 - L2 & 1 \\
\hline 4 & L2 - L4 & 5 \\
\hline 5 & L4 - L6 & 6,2 \\
\hline 6 & L6 - L5 & 3 \\
\hline & Total Jarak & 44,3 \\
\hline
\end{tabular}

Berdasarkan hasil perhitungan menggunakan teknik penukaran titik, selanjutnya diketahui selisih antar keduanya. Adapun perbandingannya sebagai berikut :

Tabel 10. Perbandingan Jarak Lintasan Awal dengan Jarak Setelah Ditukar

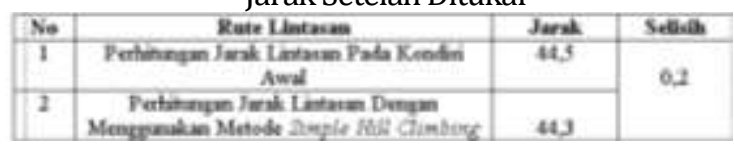

Bedasarkan tabel 10 kondisi awal (lintasan awal) sebelum dilakukan perbaikan nilai jarak lintasan yaitu 44,5 km, dan setelah dilakukan perbaikan dengan teknik menukar titik, ditemukan lintasan yang mempunyai jarak terpendek yaitu 44,3 km. Kedua angka tersebut berselisih 0,2 km. 


\section{INTERPRETASI DATA}

Perhitungan dalam menentukan jarak antar lokasi dapat ditemukanmenggunakan bantuan aplikasi peta digital atau sejenis. Setelah jarak antar lokasi diketahui selanjutnya dijumlahkan untuk mengetahui jarak satu lintasan. Pada tabel 5 dan tabel 10 menunjukkan bahwa perbanding hasil perhitungan jarak lintasan pada kondisi awal dan perhitungan jarak lintasan menggunakan metode Simple Hill Climbing menghasilkan jarak lintasan yang berbeda. Selisih jarak antara keduanya baik berdasarkan lintasan dan koordinat keduanya menunjukkan pengurangan jarak tempuh yaitu 1,2 km untuk lintasan dan 0,2 km untuk koordinat.

\section{PENUTUP}

Hasil perhitungan jarak lintasan awal atau kondisi lintasan awal yaitu diperoleh lintasan L1 - L2 L3 - L3 - L4 - L5 - L6 - L1 dijumlahkan menjadi 47,1 Km. Perhitungan menggunakan metode Simple Hill Climbing diperoleh lintasan L1 - L3 - L2 - L4 - L5 - L6 L1 dijumlahkan menjadi 45,9 Km. Dari kedua perhitungan jarak tersebut terlihat adanya perbedaan, dimana selisih jaraknya yaitu $1,2 \mathrm{Km}$.

Sedangkan perhitungan koordinat awal dengan lintasan L6,L1,L2,L3,L4,L5,L6 dengan jarak 44,5 km, dan kondisi koordinat perbaikan dengan lintasan L5,L1,L3,L2,L4,L6,L5 dengan jarak 44,3 km, sehingga selisih jarak 0,2 km.

\section{UCAPAN TERIMA KASIH}

Ucapan terima kasih ditujukan kepada pihak perusahaan Supplier Hotel yang telah memberi izin untuk pengambilan data. Terucap terima kasih juga ditujukan kepada jurnal terdahulu yang membantu dalam memberikan refrensi atau rujukan penelitian ini sehingga dikembangkan untuk penelitian kedepannya.

\section{DAFTAR PUSTAKA}

Anshori, M., Fudhla, A. F., \& Hidayat, A. (2017). Penentuan Lokasi Fasilitas Crossdock pada Kota Metropolis dengan Pendekatan Center Of Gravity. Teknika: Engineering and Sains Journal, 1(2), 83-88.

Aristi, G. (2014). Perbandingan alogaritma greedy, alogaritma cheapest insertion heuristics dan dynamic programming dalam penyelesaian travelling salesman problem. Paradigma Jurnal Komputer dan Informatika, 16(2), 5258

Dangkua, E. V., Gunawan, V., Adi, K. (2015) Penerapan metode simple hill climbing pada sistem informasi geografis untuk mencari lintasan terpendek. JSINBIS - Jurnal Sistem Informasi Bisnis, 5(1), 19-25

Dermawan, D., \& Ramadiansyah, V. (2018) Analisis distribusi obat dengan pendekatan travelling salesman problems (tsp) di pt. Pharos cabang pekanbaru. Jurnal Teknik Industri Terintegrasi, 1 (2), 1 - 8.

Setiyani, R. N., \& Abrori, M. (2015). Implementasi alogaritma best-first search (befs) pada penyelesaian traveling salesman problem (tsp) (stuti kasus: perjalanan wisata di kota yogyakarta). Jurnal Fourier, 4(2), 43647 